\title{
Virulence of white spot syndrome virus (WSSV) isolates may be correlated with the degree of replication in gills of Penaeus vannamei juveniles
}

\author{
M. M. Rahman ${ }^{1,2}$, M. Corteel $^{2}$, C. M. Escobedo-Bonilla ${ }^{1,2}$, M. Wille $^{1}$, V. Alday-Sanz ${ }^{3}$, \\ M. B. Pensaert ${ }^{2}$, P. Sorgeloos ${ }^{1}$, H. J. Nauwynck ${ }^{2, *}$ \\ ${ }^{1}$ Laboratory of Aquaculture \& Artemia Reference Center, Faculty of Bioscience Engineering, Ghent University, Rozier 44, \\ 9000 Ghent, Belgium \\ ${ }^{2}$ Laboratory of Virology, Faculty of Veterinary Medicine, Ghent University, Salisburylaan 133, 9820 Merelbeke, Belgium \\ ${ }^{3}$ Portal del Angel 3-5, 08002 Barcelona, Spain
}

\begin{abstract}
A standardized inoculation model was used in 2 separate experiments to gauge the virulence of 3 white spot syndrome virus (WSSV) isolates from Thailand and Vietnam (WSSV Thai-1, WSSV Thai-2, and WSSV Viet) in Penaeus vannamei juveniles. Mortality patterns (Expt 1) were compared and WSSV-positive cells quantified (Expt 2) in tissues following intramuscular inoculation of shrimp with the most (WSSV Thai-1) and least (WSSV Viet) virulent isolates as determined by Expt 1. The results of Expt 1 demonstrated that mortalities began at $36 \mathrm{~h}$ post inoculation (hpi) for both Thai isolate groups and at 36 to $60 \mathrm{hpi}$ for the Viet isolate group. Cumulative mortality reached $100 \% 96$ to $240 \mathrm{~h}$ later in shrimp challenged with the WSSV Viet isolate compared to shrimp challenged with the Thai isolates. WSSV infection was verified in all groups by indirect immunofluorescence. In Expt 2, WSSV-infected cells were quantified by immunohistochemical analysis of both dead and timecourse sampled shrimp. WSSV-positive cells were detected in tissues of Thai-1 inoculated dead and euthanized shrimp from 24 hpi onwards and from 36 hpi onwards in shrimp injected with the Viet isolate. Significantly more infected cells were found in tissues of dead shrimp inoculated with the Thai1 than in Viet isolate-inoculated shrimp. In these experiments, substantial differences in virulence were demonstrated between the WSSV isolates. The Vietnamese isolate induced a more chronic disease and mortality pattern than was found for the Thai isolates, possibly because it infected fewer cells. This difference was most pronounced in gills.
\end{abstract}

KEY WORDS: WSSV · Virulence - Quantitative analysis · Penaeus vannamei

\section{INTRODUCTION}

White spot syndrome virus (WSSV) is an enveloped, double-stranded DNA virus (Van Hulten et al. 2001a), which is pathogenic to decapod crustaceans including penaeid shrimp, caridean shrimp, crayfish, crabs, and lobsters (Flegel 2006). The first WSSV epidemic was reported in shrimp farms of Southeast Asia in 1992 (Chou et al. 1995). The virus then spread to other shrimp-farming countries in Asia, the Americas, and the Middle East (Lightner 1996, Rosenberry 2002, Fle- gel 2006). WSSV is considered to be among the most prevalent viruses in farmed shrimp and is responsible for a large part of crop failures (Flegel 2006). Different forms of WSSV outbreaks (peracute, acute, and chronic) in shrimp farms have been reported (Sudha et al. 1998). With its high prevalence and wide geographic distribution and host range, it is plausible that over time, WSSV has evolved into strains with different characteristics, such as virulence.

Virulence has been defined as the power of a pathogen to produce disease within a group or species (Sha- 
piro-Ilan et al. 2005). Differences in virulence between WSSV isolates have been suggested through challenge studies in shrimp and crayfish (Wang et al. 1999, Lan et al. 2002, Marks et al. 2005). However, those studies were performed without using a standardized challenge procedure to deliver a specific dose of infectious virus. Genomic and antigenic variations between WSSV strains have been reported (Wang et al. 2000, Marks et al. 2004). Previous studies have reported conflicting findings concerning the effect of genomic deletions on WSSV strain virulence (Lan et al. 2002, Marks et al. 2005).

Inside its host, WSSV targets tissues of ectodermal and mesodermal origin. Qualitative (Chang et al. 1996, Lo et al. 1997) and quantitative pathogenesis analyses (Tan et al. 2001, Durand \& Lightner 2002, EscobedoBonilla et al. 2007) have shown that the virus replicates mainly in the gills, cuticular epithelium of the stomach and body wall, hematopoietic tissue, antennal gland, and lymphoid organ. To our knowledge, quantitative analysis of virus-positive cells as a means of comparing virulence between different WSSV isolates has not been previously reported.

The objective of this study was to assess the virulence of 3 different WSSV geographic isolates (WSSV Thai-1, WSSV Thai-2, and WSSV Viet) by (i) comparing mortality patterns of specific pathogen free (SPF) Penaeus vannamei juveniles of the same age/size class following intramuscular inoculation with same infectious dose $\left(30 \mathrm{SID}_{50}\right.$, where $\mathrm{SID}_{50}=$ shrimp infectious dose with $50 \%$ endpoint) of each isolate and (ii) immunohistochemical quantification of WSSV-positive cells in specific tissues of shrimp injected with 30 SID $_{50}$ of the most and least virulent isolates.

\section{MATERIALS AND METHODS}

Virus. Three WSSV isolates were used in this study. All 3 isolates were collected from naturally infected Penaeus monodon, 2 from Thailand in 1996 and 1 from Vietnam in 2003. WSSV Thai-1 was first amplified in crayfish Pacifastacus leniusculus (Jiravanichpaisal et al. 2001), WSSV Thai-2 in Procambarus clarkii (Van Hulten et al. 2001b), and WSSV Viet in Cherax quadricarinatus. A crayfish gill suspension of WSSV Thai-1 was provided by K. Söderhäll (Uppsala University, Sweden), purified WSSV Thai-2 was given by J. M. Vlak (Wageningen University, The Netherlands), and a gill suspension of WSSV Viet was received from the Research Institute for Aquaculture No. 2, Vietnam. Each isolate was further amplified in SPF Penaeus vannamei juveniles, and infective titers of the viral stock solutions were determined according to the procedure described by Escobedo-Bonilla et al. (2005). The me- dian infectious titers of these stocks, as determined by intramuscular inoculation of SPF $P$. vannamei, were $10^{5.8}, 10^{5.9}$, and $10^{5.8} \mathrm{SID}_{50} \mathrm{ml}^{-1}$ for WSSV Thai-1, WSSV Thai-2, and WSSV Viet, respectively.

Experimental conditions and shrimp. SPF Penaeus vannamei were imported from Molokai Sea Farms, Hawaii (USA), as early postlarvae and reared in a recirculation system $\left(27\right.$ to $28^{\circ} \mathrm{C}$, salinity 34 to $36 \mathrm{~g} \mathrm{l}^{-1}$ ) at the Laboratory of Aquaculture \& Artemia Reference Center, Faculty of Bioscience Engineering, Ghent University, Belgium. Shrimp were acclimatized to a salinity of $15 \mathrm{~g} \mathrm{l}^{-1}$ over $4 \mathrm{~d}$ and then transported to the Laboratory of Virology, Faculty of Veterinary Medicine, Ghent University, where 2 separate WSSV infectivity experiments, hereafter referred to as Expts 1 and 2, were conducted. In Expt 1, 3 replicate bioassays were performed to compare the clinical effects and degree of virulence of the $3 \mathrm{WSSV}$ isolates following inoculation of the test shrimp. In Expt 2, a single bioassay was conducted to quantify WSSV-infected cells in selected tissues of time-course sampled shrimp following inoculation with either the most (Thai-1) or least virulent (Viet) of the 3 WSSV isolates as determined in Expt 1. In each bioassay, test shrimp were stocked in $50 \mathrm{l}$ aquariums containing $15 \mathrm{~g} \mathrm{l}^{-1}$ artificial sea water (Instant Ocean, Aquarium Systems), equipped with aeration, mechanical filter (Eheim), and aquarium heater (Model VTX 300, Aquarium Systems) for temperature maintenance $\left(27^{\circ} \mathrm{C}\right)$. During each bioassay, each shrimp received a daily ration of $\sim 0.2 \mathrm{~g}$ of a commercial shrimp diet (INVE). Ionized ammonia $\left(\mathrm{NH}_{4}{ }^{+}\right)$levels were checked daily using an Aquamerck test kit, and a $90 \%$ water exchange was performed on all tanks every $5 \mathrm{~d}$.

WSSV inoculation procedure. Shrimp were inoculated intramuscularly with $50 \mu \mathrm{l}$ of inoculum containing $30 \mathrm{SID}_{50}$ of each isolate in the junction between the third and fourth abdominal segments. An accurate syringe (P/N: 81001/00, 1710 LT, $100 \mu$ l, Hamilton Bonaduz) mounted with a 25 gauge needle (Terumo) was used for this purpose.

Design of Expt 1. Comparison of clinical outcome. The 3 WSSV isolates (WSSV Thai-1, WSSV Thai-2, and WSSV Viet) were used for bioassays in this experiment. Bioassays were repeated 3 times. Six 501 tanks ( 2 tanks per isolate) were stocked with 9 to 11 shrimp $\operatorname{tank}^{-1}(\mathrm{n}=59$ to 62 per bioassay, $8.8 \pm 2.6 \mathrm{~g}$ mean body weight). Following inoculation with the 3 different isolates, shrimp were monitored for signs of WSS, including anorexia and lethargy, every $12 \mathrm{~h}$ until the end of each bioassay. Dead shrimp were collected 4 times per day and analyzed by indirect immunofluorescence (IIF) for the presence of WSSV. Each bioassay was terminated when $100 \%$ mortality was obtained in all 3 treatment groups. The clinical outcome was mea- 
sured by the following parameters: (1) time to onset of disease symptoms, (2) time to onset of mortality, (3) time to reach $100 \%$ cumulative mortality, and (4) median lethal time.

Design of Expt 2. Comparison of lesion development in target tissues. The findings of Expt 1 indicated that the Thai-1 and Viet WSSV isolates were the most and least virulent, respectively, of the 3 isolates tested and were used in this bioassay. Ten 501 tanks were each stocked with 9 to 10 shrimp $(n=99,16.6 \pm 2.8 \mathrm{~g}$ mean body weight). Thirty-nine shrimp were inoculated with the Thai-1 isolate and distributed among 4 tanks. Sixty shrimp were inoculated with the Viet isolate and equally divided among the remaining 6 tanks. Five shrimp from both treatment groups were euthanized at $0,12,24,36,48$, and 72 hpi by burying in ice. The only exception to this were the WSSV Thai-1 72 hpi samples for which only 2 surviving shrimp could be collected. In addition, 5 WSSV Viet-inoculated shrimp were euthanized at 120 and $168 \mathrm{hpi}$. When observed, dead shrimp were also collected. WSSVinfected cells were quantified by immunohistochemistry (IHC) in gills, cuticular epithelium of stomach and body wall, hematopoietic tissue, and antennal gland of all euthanized and dead shrimp.

Demonstration of WSSV by IIF. Detection of WSSV by IIF in the dead shrimp collected during Expt 1 was performed according to the procedure of EscobedoBonilla et al. (2005). In brief, the cephalothorax of shrimp was bisected midsagittally, embedded in $2 \%$ methylcellulose, and frozen $\left(-20^{\circ} \mathrm{C}\right)$. Cryosections $(5 \mu \mathrm{m})$ were prepared and fixed in $100 \%$ methanol at $-20^{\circ} \mathrm{C}$ for $20 \mathrm{~min}$. Sections were washed in phosphatebuffered saline (PBS) and incubated $\left(1 \mathrm{~h}, 37^{\circ} \mathrm{C}\right)$ with $2 \mu \mathrm{g} \mathrm{ml}^{-1}$ of the monoclonal antibody 8B7 (Diagxotics) directed against viral protein VP28 (Poulos et al. 2001). Sections were washed in PBS and incubated $(1 \mathrm{~h}$, $37^{\circ} \mathrm{C}$ ) with fluorescein isothiocyanate (FITC)-labeled goat anti-mouse IgG (F-2761, Molecular Probes). Sections were finally washed in PBS, rinsed in deionized water, briefly dried, mounted with a solution of glycerin and 1,4-diaza-bicyclo[2,2,2]-octan (ACROS Organics), and analyzed by fluorescence microscopy (Leica DM RBE).

Quantification of WSSV-infected cells by IHC. The cephalothorax of dead and time-course sampled shrimp (Expt 2) was bisected midsagittally upon collection, fixed in Davidson's solution for 48 to $72 \mathrm{~h}$ (Bell \& Lightner 1988), and then transferred to $50 \%$ ethanol. Both halves were paraffin-embedded in separate cassettes, and $5 \mu \mathrm{m}$ sections were prepared. One half of the cephalothorax was used to produce gill sections, the other for sections of the stomach, body wall, hematopoietic tissue, and antennal gland. The resulting sections were mounted on silane-coated slides (A3648,
Sigma-Aldrich) and analyzed by IHC for WSSV according to the protocol of Escobedo-Bonilla et al. (2007). Tissue sections were deparaffinized by heating at 55 to $60^{\circ} \mathrm{C}$ for $30 \mathrm{~min}$ followed by immersion in xylene. They were rehydrated by immersion in a series of ethanol baths ranging from 100 down to $50 \%$. Endogenous peroxidase was blocked by a 30 min incubation at room temperature (RT) in a solution of sodium azide $(1 \%)$ and hydrogen peroxidase $(0.02 \%)$ in Tris buffer ( $\mathrm{pH} 7.4$ ). Sections were subsequently incubated for $1 \mathrm{~h}$ $\left(37^{\circ} \mathrm{C}\right)$ with an anti-WSSV VP28 monoclonal antibody (Poulos et al. 2001) at $2 \mu \mathrm{g} \mathrm{ml}^{-1}$ (8B7, Diagxotics). Sections were washed in Tris buffer ( $\mathrm{pH} 7.6)$ and incubated $\left(1 \mathrm{~h}, 37^{\circ} \mathrm{C}\right)$ with 1:200 dilution of biotinylated sheep antimouse IgG antibodies (RPN 1001, Amersham Biosciences) followed by washing and incubation (30 min, RT) in streptavidine-biotinylated horseradish peroxidase complex (RPN 1051, Amersham Biosciences). Finally, tissues were incubated for $30 \mathrm{~min}$ in $0.01 \%$ of 3, 3'-diaminobenzidine (D8001, Sigma Aldrich) for color development, counterstained with Gill's hemaluin, washed, dehydrated, and coverslipped (DPX mountant for histology, Fluka, Biochemika, 44581).

WSSV-infected cells were counted by light microscopy (Leica DM RBE) using 400× magnification according to the protocol of Escobedo-Bonilla et al. (2007). Briefly, 5 fields containing gills and 2 to 3 fields of hematopoietic tissue were randomly selected and WSSVinfected cells were counted. This number was converted to the number of WSSV-infected cells per mm. In contrast, 5 fields containing stomach epithelium, body wall epithelium, or antennal gland were selected at random, and both WSSV-infected and uninfected epithelial cells were quantified to allow calculation of the average percentage of infected cells.

Statistical analyses. Cumulative mortality data generated by the 3 bioassays (Expt 1) was analyzed by probit (Agresti 1996). When no significant interactions exist between time and isolate, the probit model has the form:

$$
\text { Probit }(x)=\alpha+\beta \text { time }+\gamma \text { isolate }
$$

where $\alpha$ is the intercept, $\beta$ is the rate of probability change per unit change of time (for a constant isolate), and $\gamma$ is the rate of probability difference for each isolate (for a constant time).

The parameters of this model were determined using the statistical software S-plus version 6.1 (Lucent Technologies). Differences between isolates were determined by $t$-tests using the same statistical software. The differences in numbers of WSSV-infected cells between naturally deceased shrimp and euthanized shrimp samples collected at 36, 48, and $72 \mathrm{hpi}$ with the Thai-1 or Viet isolates (Expt 2) were analyzed per tissue by $t$-test using the same statistical software. 


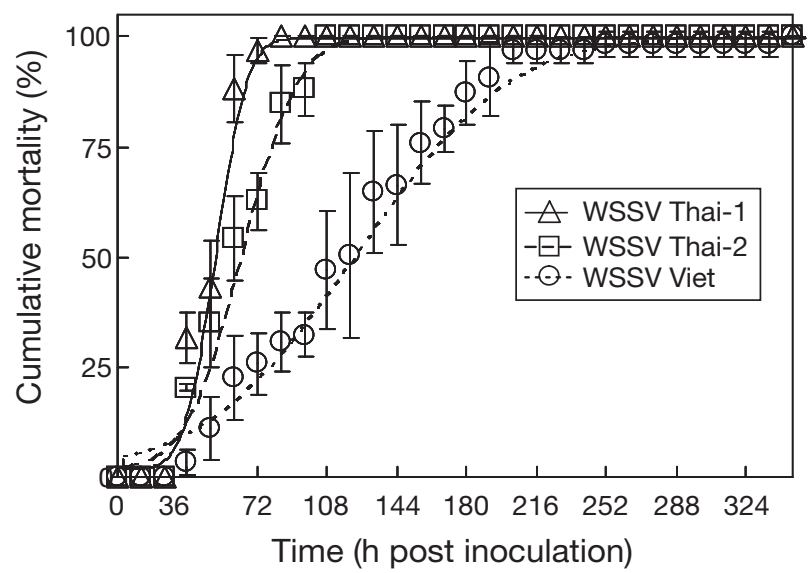

Fig. 1. Penaeus vannamei. Cumulative mortalities (mean \pm $\mathrm{SD}$ ) derived from 3 replicate bioassays of specific pathogenfree (SPF) juveniles inoculated intramuscularly with 30 shrimp infection dose $\left(\operatorname{SID}_{50}\right)$ of white spot syndrome virus (WSSV) ( $\triangle$ WSSV Thai-1, $\square$ WSSV Thai-2, O WSSV Viet). Probability of mortality of shrimp (probit) inoculated intramuscularly with 30 SID $_{50}$ of WSSV (- WSSV Thai-1, -.-... WSSV Thai-2, -..... WSSV Viet)

\section{RESULTS}

Expt 1. Comparison of clinical outcome. Clinical signs of anorexia and lethargy were first observed in the shrimp inoculated with each of the 3 isolates from 24 to $36 \mathrm{hpi}$. Mortalities began 36 hpi with both Thai isolates and 36 to 60 hpi with the Viet isolate in the 3 bioassays (Fig. 1). Cumulative mortalities reached $100 \%$ at 72 to $84 \mathrm{hpi}, 108 \mathrm{hpi}$, and 204 to $348 \mathrm{hpi}$ in shrimp inoculated with WSSV Thai-1, WSSV Thai-2, and WSSV Viet, respectively. All dead shrimp $(\mathrm{n}=181)$ were WSSV-positive by IIF. Median lethal times $\left(\mathrm{LT}_{50}\right)$ of the Thai-1, Thai-2, and Viet isolates were 47, 61 , and $120 \mathrm{hpi}$, respectively, and were significantly different from one another (Table $1 ; \mathrm{p}<0.05$ ). These collective results show that WSSV Thai-1 and WSSV Viet are the most and least virulent isolates, respectively, of the 3 isolates tested.

Expt 2. Comparison of lesion development in target tissues. WSSVinfected cells were detected by IHC in each of the 5 tissues (gills, antennal gland, hematopoietic tissue, and epithelium of the stomach and body wall) analyzed from the euthanized Thai-1inoculated shrimp from 24 hpi onwards
(Table 2). In contrast, WSSV-infected cells were only detected in the gills and cuticular epithelium of the stomach of 24 hpi Viet-inoculated shrimp. From 36 hpi onwards, all 5 tissue types of this treatment group displayed WSSV-infected cells. The numbers of infected cells (mean $\pm \mathrm{SD}$ ) in the tissues of the euthanized shrimp collected at 36,48 , or $72 \mathrm{hpi}$ were not significantly different between the 2 isolates (Table 2). The highest numbers of infected cells were detected in each tissue of the euthanized shrimp at 48 or $72 \mathrm{hpi}$ for both isolates. Photomicrographs illustrating the distribution and relative numbers of WSSV-infected cells in the 5 tissues of Thai-1 and Viet isolate-inoculated shrimp collected at $48 \mathrm{hpi}$ are presented in Fig. 2.

Table 1. Penaeus vannamei. Median lethal times $\left(\mathrm{LT}_{50}\right)$ determined by probit analysis of juveniles inoculated intramuscularly with 30 SID $_{50}$ of WSSV Thai-1, WSSV Thai-2, or WSSV Viet (with $\alpha$ being the intercept, $\beta$ the rate of probability change per unit change in time and $\gamma$ the rate of probability difference for each isolate). Different superscripts denote significant differences in $\mathrm{LT}_{50}(\mathrm{p}<0.05)$

\begin{tabular}{|lcccc|}
\hline WSSV isolates & $\mathrm{LT}_{50}$ & $\alpha$ & $\beta$ & $\gamma$ \\
\hline Thai-1 & $46.9^{\mathrm{a}}$ & 3.713 & -0.0792 & \\
Thai-2 & $60.8^{\mathrm{b}}$ & 3.713 & -0.0792 & -1.035 \\
Viet & $119.7^{\mathrm{c}}$ & 3.713 & -0.0792 & -1.776 \\
\hline
\end{tabular}

Table 2. Penaeus vannamei. Quantification of WSSV-infected cells by immunohistochemistry in time-course sampled and dead SPF juveniles post-intramuscular inoculation with 30 SID $_{50}$ of WSSV Thai-1 or WSSV Viet. Numbers of infected cells in the same tissue with the same superscript were not significantly different between the 2 isolates $(\mathrm{p}>0.05)$. hpi: h post inoculation

\begin{tabular}{|c|c|c|c|c|c|c|}
\hline $\begin{array}{l}\text { WSSV } \\
\text { isolate }\end{array}$ & $\begin{array}{l}\text { Time } \\
\text { (hpi) }\end{array}$ & $\begin{array}{l}\text { Gills } \\
\left(\mathrm{mm}^{-2}\right)\end{array}$ & $\begin{array}{l}\text { Quantity of } \mathrm{W} \\
\text { Stomach } \\
\text { cuticular } \\
\text { epithelium } \\
(\%)\end{array}$ & $\begin{array}{l}\text { SV-infected c } \\
\text { Cuticular } \\
\text { epithelium } \\
\text { of the body } \\
\text { wall }(\%)\end{array}$ & $\begin{array}{l}\text { ls in tissue } \\
\text { Hemato- } \\
\text { poietic } \\
\text { tissue } \\
\left(\mathrm{mm}^{-2}\right)\end{array}$ & $\begin{array}{c}\text { Antennal } \\
\text { gland } \\
(\%)\end{array}$ \\
\hline \multicolumn{7}{|c|}{ Time-course sampled individuals } \\
\hline \multirow[t]{6}{*}{ Thai-1 } & 0 & 0 & 0 & 0 & 0 & 0 \\
\hline & 12 & 0 & 0 & 0 & 0 & 0 \\
\hline & 24 & $2 \pm 1$ & $1 \pm 1$ & $0.1 \pm 0.2$ & $2 \pm 4^{\mathrm{a}}$ & $0.3 \pm 0.7$ \\
\hline & 36 & $31 \pm 53^{\mathrm{a}}$ & $4 \pm 7^{a}$ & $5 \pm 6^{\mathrm{a}}$ & $42 \pm 57^{\mathrm{a}}$ & $2 \pm 4^{\mathrm{a}}$ \\
\hline & 48 & $276 \pm 318^{a}$ & $18 \pm 18^{\mathrm{a}}$ & $13 \pm 14^{\mathrm{a}}$ & $257 \pm 348^{\mathrm{a}}$ & $10 \pm 14^{\mathrm{a}}$ \\
\hline & 72 & $342 \pm 479^{a}$ & $18 \pm 26^{a}$ & $17 \pm 24^{a}$ & $58 \pm 83^{a}$ & $5 \pm 8^{a}$ \\
\hline \multirow[t]{8}{*}{ Viet } & 0 & 0 & 0 & 0 & 0 & 0 \\
\hline & 12 & 0 & 0 & 0 & 0 & 0 \\
\hline & 24 & $3 \pm 4$ & $0.1 \pm 0.1$ & 0 & 0 & 0 \\
\hline & 36 & $9 \pm 16^{\mathrm{a}}$ & $6 \pm 11^{\mathrm{a}}$ & $3 \pm 5^{\mathrm{a}}$ & $109 \pm 232^{\mathrm{a}}$ & $0.5 \pm 0.5^{\mathrm{a}}$ \\
\hline & 48 & $114 \pm 52^{\mathrm{a}}$ & $24 \pm 13^{\mathrm{a}}$ & $21 \pm 8^{\mathrm{a}}$ & $308 \pm 195^{\mathrm{a}}$ & $3 \pm 2^{\mathrm{a}}$ \\
\hline & 72 & $101 \pm 26^{a}$ & $24 \pm 3^{\mathrm{a}}$ & $18 \pm 6^{\mathrm{a}}$ & $56 \pm 41^{\mathrm{a}}$ & $5 \pm 2^{\mathrm{a}}$ \\
\hline & 120 & $58 \pm 10$ & $27 \pm 6$ & $18 \pm 15$ & $106 \pm 111$ & $2 \pm 1$ \\
\hline & 168 & $17 \pm 6$ & $14 \pm 6$ & $13 \pm 9$ & $140 \pm 95$ & $2 \pm 2$ \\
\hline \multicolumn{7}{|c|}{ Dead individuals } \\
\hline \multicolumn{2}{|l|}{ Thai-1 } & $523 \pm 321^{a}$ & $38 \pm 7^{a}$ & $28 \pm 8^{\mathrm{a}}$ & $259 \pm 155^{a}$ & $11 \pm 6^{a}$ \\
\hline \multicolumn{2}{|l|}{ Viet } & $86 \pm 63^{b}$ & $23 \pm 8^{\mathrm{b}}$ & $18 \pm 8^{\mathrm{b}}$ & $160 \pm 103^{a}$ & $5 \pm 3^{b}$ \\
\hline
\end{tabular}



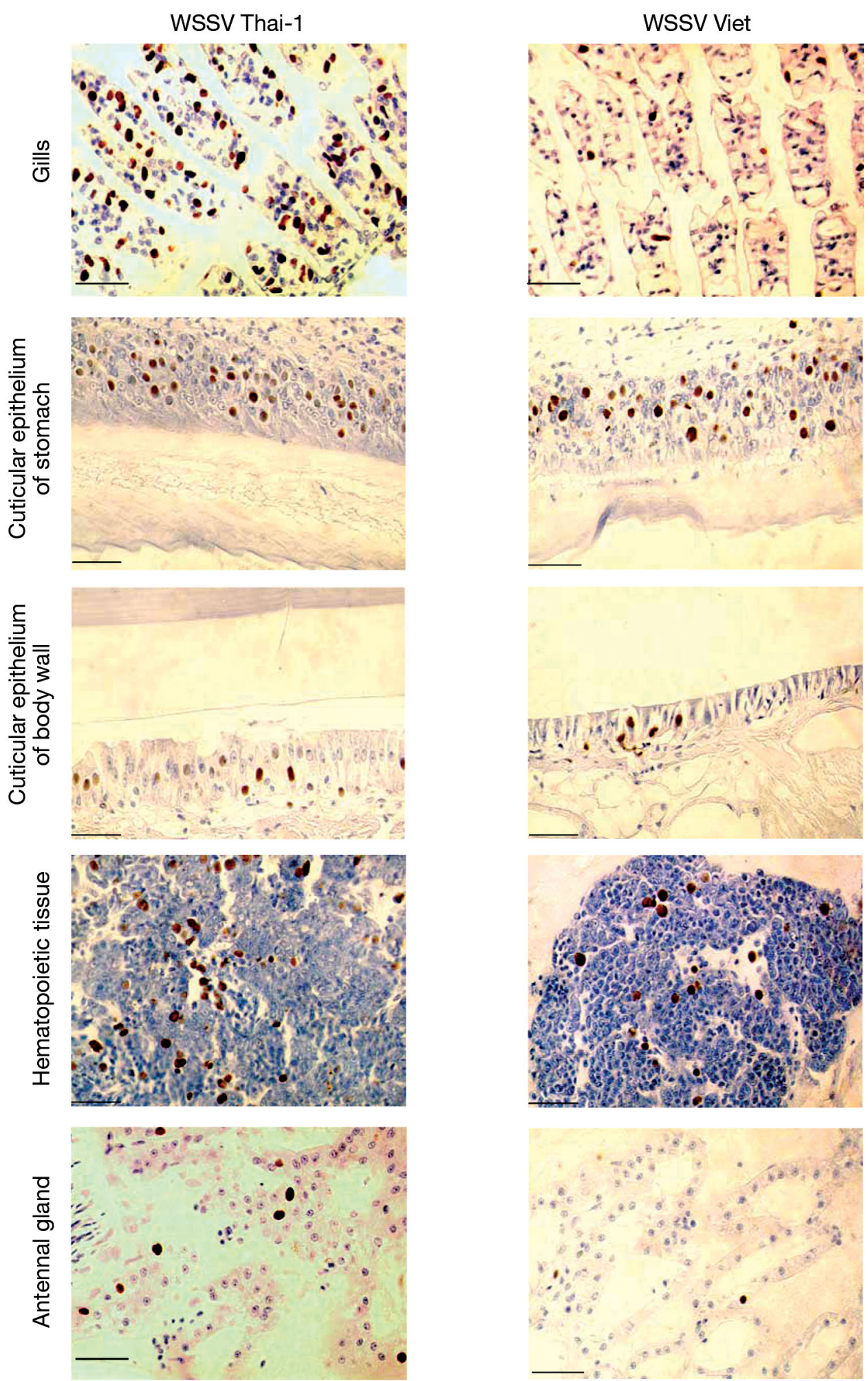

Fig. 2. Penaeus vannamei. Photomicrographs of WSSV-infected gills, cuticular epithelia of stomach and body wall, hematopoietic tissues, and antennal glands of juveniles sampled at $48 \mathrm{~h}$ post-intramuscular inoculation with 30 SID $_{50}$ of either WSSV Thai-1 or WSSV Viet. Infected cells were detected by immunohistochemistry using a monoclonal antibody directed against VP28. Scale bars $=50 \mu \mathrm{m}$ 
WSSV-infected cells were detected in each of the 5 tissue types of all dead shrimp collected from both the Thai-1 and Viet isolate treatment groups (Table 2). The number of WSSV-infected cells was significantly greater $(p<0.05)$ in the gills, cuticular epithelium of the stomach, cuticular epithelium of the body wall, and antennal gland of the Thai-1 versus the Viet samples. This difference was most pronounced in gill sections, where Thai-1 samples contained around 6 times the number of WSSV-infected cells compared to Viet samples. In contrast, the number of WSSV-infected cells in hematopoietic tissues did not differ significantly between the 2 isolates.

\section{DISCUSSION}

Expt 1 demonstrated the existence of clear differences in virulence between the 3 isolates, Thai-1, Thai-2 and Viet, by comparing time to onset of mortality (36, 36, and 36-60 hpi, respectively), time to reach $100 \%$ cumulative mortality $(72-84,108$, and 204-348 hpi, respectively), and median lethal time $(47,61$, and $120 \mathrm{hpi}$, respectively). These findings were further corroborated by the results of Expt 2, which demonstrated that Thai-1 exposed deceased shrimp contained a significantly higher number of WSSV-infected cells in 4 of the 5 tissues examined than Viet-exposed samples. These collective findings indicated that Thai-1 was the most virulent WSSV isolate of the 3 isolates tested and that the Viet isolate was the least virulent. Furthermore, the results demonstrated the effectiveness and reproducibility of intramuscular inoculation of a defined WSSV infectious titer $\left(30 \mathrm{SID}_{50}\right)$ in SPF Penaeus vannamei juveniles of the same age. This methodology can be used to evaluate the virulence of other WSSV geographical isolates and may be applicable for virulence analysis of other viral diseases. We have demonstrated that virulence differences exist between WSSV geographic isolates using a standardized inoculation procedure that delivers a fixed viral dose, and these findings confirm similar suppositions made in previous studies (Wang et al. 1999, Lan et al. 2002, Marks et al. 2005).

Quantification of WSSV-infected cells (VP28 positive) in 5 tissue types of naturally deceased and euthanized shrimp was performed with the aim of finding a possible explanation for the differences in virulence that had been established in Expt 1. For this purpose, tissues targeted by WSSV that serve vital physiological roles in shrimp were selected. Gills are essential for respiration, osmoregulation, excretion, and acid-base homeostasis (Taylor \& Taylor 1992); the stomach plays a role in digestion (Icely \& Nott 1992); cuticular epithelium produces cuticula, which forms a physical barrier against pathogen invasion (Brey et al. 1993); hematopoietic tissue produces hemocytes, which are pivotal in the defense system; and the antennal gland is the main excretory organ of shrimp (Felgenhauer 1992). The most plausible explanation for the generally faster rate of mortality that occurred in shrimp inoculated with WSSV Thai1 compared to those infected with the other 2 isolates is a more pronounced dysfunction due to more necrosis of cells because of increased replication of WSSV. Especially in the gills, an organ that can be considered particularly vital, the average number of positive cells was 6 times higher in dead WSSV Thai1-inoculated shrimp than in dead shrimp that had been inoculated with WSSV Viet. This higher number may have been the result of 1 or a combination of the following factors. (1) The replication cycle of WSSV Thai-1 may have been shorter than that of WSSV Viet. This can only be examined in detail when shrimp cell lines become available. (2) More cell types may have been susceptible to infection with WSSV Thai-1. Within gills, 6 cell types have been differentiated: chief cells, pillar cells, striated cells, glycocytes, nephrocytes, and granular cells (Felgenhauer 1992). Genomic differences between WSSV Thai-1 and WSSV Viet have in fact been demonstrated (J. M. Vlak pers. comm.), and these differences could be responsible for allowing the viruses to infect different cell types in the host. With other viruses it has already been shown that genomic variation may result in a shift of receptor usage, and as a consequence, a shift in target cell in the host (Baranowski et al. 2001). The lack of cell markers for most shrimp cell types hinders further research to confirm the hypothesis on cell specificity. (3) The host defense response during a WSSV Thai-1 infection may have been less effective than that during a WSSV Viet infection. This hypothesis has some potential, as recent studies have shown the existence of antiviral defense in WSSV-infected shrimp, including RNA interference (Robalino et al. 2007), production of an interferon-like protein (He et al. 2005) and an anti-polysaccharide factor (Liu et al. 2006), and upregulation of antiviral gene expression (Luo et al. 2007).

Overall, the number of infected cells was high in shrimp at the time of death and thus it might be concluded that virus replication and consequent tissue damage were directly linked with death of the host. However, a few shrimp inoculated with the less virulent WSSV Viet died early (36 hpi) at a time when only few infected cells were present. This indicated that other factors were probably contributing to shrimp death, even when the infection had not yet progressed much. One of these factors could be stress caused by 
the molting process (Mugnier et al. in press). In order to account for and exclude shrimp mortality due to factors other than WSSV infection, it is important to include mock-inoculated shrimp (negative controls) in future studies of this type.

Quite large variations in numbers of infected cells were observed between individual shrimp inoculated with both WSSV isolates. These variations in viral load of individual shrimp have also been reported by other authors (Tan et al. 2001, Durand \& Lightner 2002) and can probably be explained by differences in degree of virus replication, physiological state, and defense response of the host.

In conclusion, we showed that intramuscular inoculation with $30 \mathrm{SID}_{50}$ in Penaeus vannamei juveniles can be used as a tool to compare virulence of WSSV isolates. Immunohistochemistry yielded clear indications that the severity of infection in certain tissues, especially the gills, may be used to determine the degree of virulence of different WSSV isolates.

Acknowledgements. M.M.R. acknowledges a PhD scholarship from the Belgian Technical Cooperation (BTC). M.C. received a scholarship from the Institute for the Promotion of Innovation by Science and Technology in Flanders (IWT, Belgium). The authors thank Dr. J. Brock for kind assistance in editing the manuscript.

\section{LITERATURE CITED}

Agresti A (1996) An introduction to categorical data analysis. John Wiley, New York

Baranowski E, Ruiz-Jarabo CM, Domingo E (2001) Evolution of cell recognition by viruses. Science 292:1102-1105

Bell TA, Lightner DV (1988) A handbook of normal penaeid shrimp histology. The World Aquaculture Society, Baton Rouge, LA

Brey PT, Lee W, Yamakawa M, Koizumi Y, Perrot S, Francois M, Ashida M (1993) Role of the integument in insect immunity: epicuticular abrasion and induction of cecropin synthesis in cuticular epithelial cells. Proc Natl Acad Sci USA 90:6275-6279

Chang PS, Lo CF, Wang YC, Kou GH (1996) Identification of white spot syndrome associated baculovirus (WSBV) target organs in the shrimp Penaeus monodon by in situ hybridization. Dis Aquat Org 27:131-139

> Chou HY, Huang CY, Wang CH, Chiang HC, Lo CF (1995) Pathogenicity of a baculovirus infection causing white spot syndrome in cultured penaeid shrimp in Taiwan. Dis Aquat Org 23:165-173

> Durand SV, Lightner DV (2002) Quantitative real time PCR for the measurement of white spot syndrome virus in shrimp. J Fish Dis 25:381-389

Escobedo-Bonilla CM, Wille M, Alday-Sanz V, Sorgeloos P, Pensaert MB, Nauwynck HJ (2005) In vivo titration of white spot syndrome virus (WSSV) in specific pathogen free Litopenaeus vannamei by intramuscular and oral routes. Dis Aquat Org 66:163-170

Escobedo-Bonilla CM, Wille M, Alday-Sanz V, Sorgeloos P, Pensaert MB, Nauwynck HJ (2007) Pathogenesis of a Thai strain of white spot syndrome virus (WSSV) in juvenile, specific pathogen-free Litopenaeus vannamei. Dis Aquat Org 74:85-94

Felgenhauer BE (1992) Internal anatomy of the Decapoda: an overview. In: Harrison FW, Humes AG (eds) Microscopic anatomy of invertebrates. Vol 10. Decapod Crustacea. Wiley-Liss, New York, p 45-75

Flegel TW (2006) Detection of major penaeid shrimp viruses in Asia, a historical perspective with emphasis on Thailand. Aquaculture 258:1-33

He N, Qin Q, Xu X (2005) Differential profile of genes expressed in hemocytes of white spot syndrome virusresistant shrimp (Penaeus japonicus) by combining suppression subtractive hybridization and differential hybridization. Antiviral Res 66:39-45

Icely JD, Nott JA (1992) Digestion and absorption: digestive system and associated organs. In: Harrison FW, Humes AG (eds) Microscopic anatomy of invertebrate. Vol 10. Decapod Crustacea. Wiley-Liss, New York, p 147-201

Jiravanichpaisal P, Bangyeekhun E, Söderhäll K, Söderhäll I (2001) Experimental infection of white spot syndrome virus in freshwater crayfish Pacifastacus leniusculus. Dis Aquat Org 47:151-157

> Lan Y, Lu W, Xu X (2002) Genomic instability of prawn white spot bacilliform virus (WSBV) and its association to virus virulence. Virus Res 90:269-274

Lightner DV (1996) A handbook of pathology and diagnostic procedures for diseases of penaeid shrimp. The World Aquaculture Society, Baton Rouge, LA

> Liu H, Jiravanichpaisal P, Söderhäll I, Cerenius L, Söderhäll K (2006) Antipolysaccharide factor interferes with white spot syndrome virus replication in vitro and in vivo in the crayfish Pacifastacus leniusculus. J Virol 80:10365-10371

Lo CF, Ho CH, Chen CH, Liu KF and others (1997) Detection and tissue tropism of white spot syndrome baculovirus (WSBV) in captured brooders of Peaneus monodon with a special emphasis on reproductive organs. Dis Aquat Org 30:53-72

> Luo T, Li F, Lei K, Xu X (2007) Genomic organization, promoter characterization and expression profiles of an antiviral gene PmAV from the shrimp Penaeus monodon. Mol Immunol 44:1516-1523

Marks H, Goldbach RW, Vlak JM, van Hulten MC (2004) Genetic variation among isolates of white spot syndrome virus. Arch Virol 149:673-697

> Marks H, van Duijse JAJ, Zuidema D, Van Hulten MCW, Vlak JM (2005) Fitness and virulence of an ancestral white spot syndrome virus isolate from shrimp. Virus Res 110:9-20

Mugnier C, Zipper E, Goarant C, Lemonnier H (2008) Combined effect of exposure to ammonia and hypoxia on the blue shrimp Litopenaeus stylirostris survival and physiological response in relation to molt stage. Aquaculture 274:398-407

Poulos BT, Pantoja CR, Bradley-Dunlop D, Aguilar J, Lightner DV (2001) Development and application of monoclonal antibodies for the detection of white spot syndrome virus of penaeid shrimp. Dis Aquat Org 47:13-23

Robalino J, Bartlett TC, Chapman RW, Gross PS, Browdy CL, Warr GW (2007) Double-stranded RNA and antiviral immunity in marine shrimp: inducible host mechanisms and evidence for the evolution of viral counter-responses. Dev Comp Immunol 31:539-547

Rosenberry B (2002) World shrimp farming. Shrimp News International, San Diego, CA

Shapiro-Ilan DI, Fuxa JR, Lacey LA, Onstad DW, Kaya HK (2005) Definitions of pathogenicity and virulence in invertebrate pathology. J Invertebr Pathol 88:1-7 
Sudha PM, Mohan CV, Shankar KM, Hegde A (1998) Relationship between white spot syndrome virus infection and clinical manifestation in Indian cultured penaeid shrimp. Aquaculture 167:95-101

Tan LT, Soon S, Lee KL, Shariff M, Hassan MD, Omar AR (2001) Quantitative analysis of an experimental white spot syndrome virus (WSSV) infection in Penaeus monodon Fabricius using competitive polymerase chain reaction. J Fish Dis 24:315-323

Taylor HH, Taylor E (1992) Gills and lungs: the exchange of gases and ions. In: Harrison FW, Humes AG (eds) Microscopic anatomy of invertebrates. Vol 10. Decapod Crustacea. Wiley-Liss, New York, p 203-293

> Van Hulten MC, Witteveldt J, Snippe M, Vlak JM (2001a)

Editorial responsibility: Ken Hasson,

College Station, Texas, USA
White spot syndrome virus envelope protein VP28 is involved in the systemic infection of shrimp. Virology 285: 228-233

> Van Hulten MC, Witteveldt J, Peters S, Kloosterboer N and others (2001b) The white spot syndrome virus DNA genome sequence. Virology 286:7-22

Wang Q, White BL, Redman RM, Lightner DV (1999) Per os challenge of Litopenaeus vannamei postlarvae and Farfantepenaeus duorarum juveniles with six geographic isolates of white spot syndrome virus. Aquaculture 170: 179-194

Wang Q, Poulos BT, Lightner DV (2000) Protein analysis of geographic isolates of shrimp white spot syndrome virus. Arch Virol 145:263-274

Submitted: July 24, 2007; Accepted: February 14, 2008

Proofs received from author(s): April 22, 2008 